The Narrative of the Institution of the Eucharist, and the Accompanying External Gestures Author(s): Vernon Staley

Source: The Irish Church Quarterly, Vol. 2, No. 8 (Oct., 1909), pp. 308-315

Published by:

Stable URL: http://www.jstor.org/stable/30066960

Accessed: 28-01-2016 10:46 UTC

Your use of the JSTOR archive indicates your acceptance of the Terms \& Conditions of Use, available at http://www.jstor.org/page/ info/about/policies/terms.jsp

JSTOR is a not-for-profit service that helps scholars, researchers, and students discover, use, and build upon a wide range of content in a trusted digital archive. We use information technology and tools to increase productivity and facilitate new forms of scholarship. For more information about JSTOR, please contact support@jstor.org. 


\section{THE NARRATIVE OF THE INSTITUTION OF THE EUCHARIST, AND THE ACCOMPANYING EXTERNAL GESTURES.}

A COMPARISON of the rubrics accompanying the Prayer of Consecration contained in the Communion Service of the First English Prayer Book of the year 1549, with those inserted in the present Prayer Book, discloses a considerable amount of development-and, from the point of view of the following article, most undesirable development. Development in matters theological and liturgical needs to be most carefully scrutinized, and in some cases to be checked and firmly withstood. To the present writer the ceremonial development which has taken place since 1549, in the matter of the celebrant's gestures during the recitation of the narrative of the institution, in the course of the Prayer of Consecration, is most unfortunate and even misleading : mor€ over, as will be demonstrated later, the directions referred to, in some details, are not only lacking in precec'ent, but are not in accordance with our Lord's example, as recorded or suggested in the Gospels.

On the following page is printed the narrative of the institution of the Eucharist, as adopted in the current Book of Common Prayer; succeeded by a comparative table, indicating the source and the stages of development of the rubrics which control the mimetic gestures of the minister, commonly known as "the Manual Acts." The narrative is quoted from the Prayer of Consecration of the Irish Book of Common Prayer (A.P.C.K., Dublin, I90I), whilst the rubrics are those of the English Prayer Book of 1662 , and which agree with those of the current Irish Prayer Book with one exception, namely, that the Irish Book has "hand" (singular) for "hands" (plural), in the direction accompanying the words, " he took the cup." The narrative is verbally identical in both Books. 


\begin{tabular}{|c|c|c|c|c|c|}
\hline 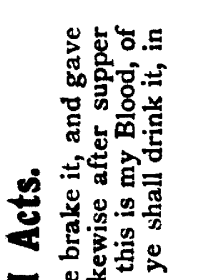 & $=$ & $\vdots$ & $\vdots$ & 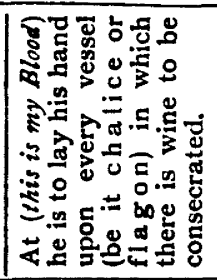 & 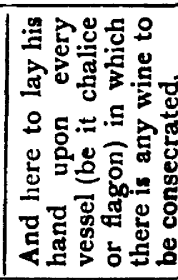 \\
\hline 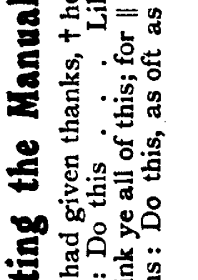 & $\infty$ & 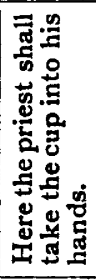 & 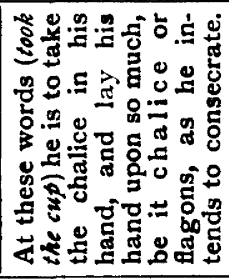 & 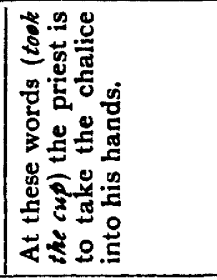 & 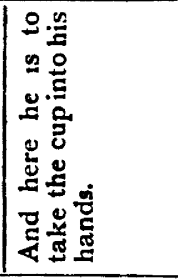 \\
\hline 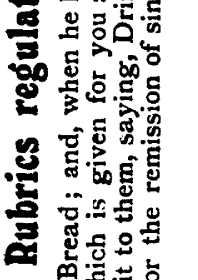 & + & $\vdots$ & $\vdots$ & 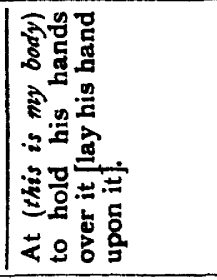 & 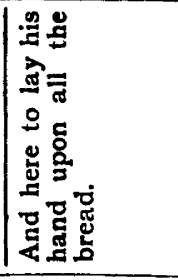 \\
\hline 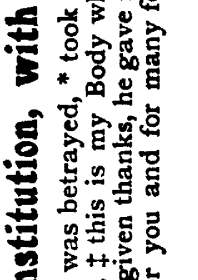 & + & $\vdots$ & $\vdots$ & 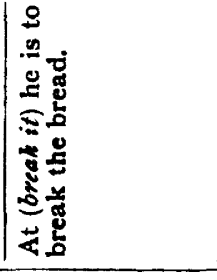 & 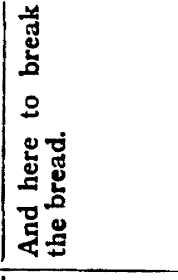 \\
\hline 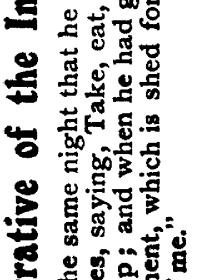 & * & 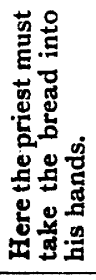 & 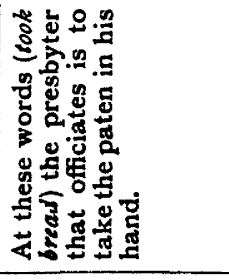 & 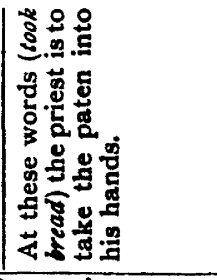 & 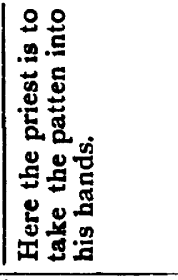 \\
\hline 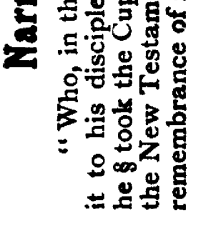 & & 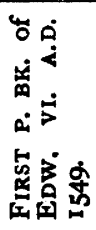 & 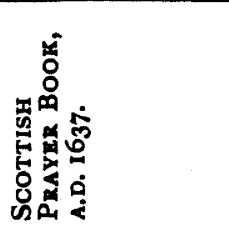 & 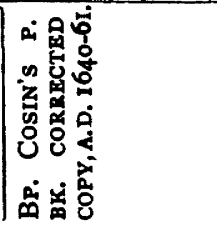 & 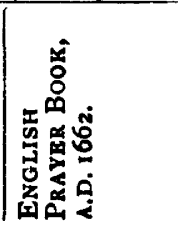 \\
\hline
\end{tabular}


From the foregoing table it will be seen that the only direction which we inherit from the Prayer Book of 1549 is the direction to take the bread and the cup into the hands, as the celebrant says, "He took bread": "He took the cup." The Scottish Prayer Book of 1637which largely influenced the Book of 1662 -carried forward the directions of the Book of 1549 , with a notable addition, namely, the order to the celebrant to lay his hand upon the chalice, at the words, "He took the cup." This addition was momentous, for it evidently suggested to the revisers of $I 662$ a like direction to lay the hand upon the bread also. But of this matter, more will be said later. The direction to break the bread first appeared in 1662 , and its introduction appears to have been due to Puritan complaints at the Savoy Conference in the previous year. On the Prayer of Consecration the Puritan party objected, "We conceive that the manner of the consecration of the elements is not here explicit and distinct enough, and the minister's breaking of the bread is not so much as mentioned."' We may trace the influence of Cosin in the additions made to the rubrics as to breaking the bread, as appears from the directions given in his Corrected Copy of the Prayer Book, 1640-166I, as shewn in the foregoing table. ${ }^{2}$

Having briefly traced the growth of the directions for " the Manual Acts," we would venture to offer some criticisms thereon.

I. The directions to take the bread and the cup into the hands at the words, "He took bread": " $\mathrm{He}$ took the cup," are in accord with ancient liturgical precedent. $^{3}$ The action may be held to signify the designation of the elements.

II. The direction to break the bread at the words, "He brake it," is open to the very gravest objection, in view of the moment specified in the rubric. That moment, be it carefully observed, is before consecration :

* Cardwell, Hist. of Conferences, vii. $32 \mathrm{I}$.

Parker, Introd. to Revisions of Book of C. P., ccxiv.

s e.g. Liturgy of St. Mark (Greek); Liturgy of Coptic Jacobites.Brightman, Liturgies Eastern and Western, $132 \mathrm{f}$; ; $176 \mathrm{f}$. 
whereas it is quite conspicuously manifest that our Lord did not break the bread until after $\mathrm{He}$ had consecrated it. The Gospel records that it was only after our Lord had blessed and given thanks, i.e., after $\mathrm{He}$ had consecrated, that $\mathrm{He}$ brake the bread in order that $\mathrm{He}$ might distribute it to His disciples. The direction as it stands in its present position in the Prayer Book is in obvious divergence from the example of Jesus Christ, and as such no possible justification for the arrangement can be pleaded. What possible right have we to invert the order of proceeding at the institution of the Eucharist? The liberty so taken by the revisers in 1662 is amazing, and their action is aggravated by the fact that in this matter they entirely failed in carrying out the terms of the King's warrant or commission for the Savoy Conference in regard to the revision, namely, " to advise upon and review the said Book of Common Prayer, comparing the same with the most ancient Liturgies which have been used in the Church, in the primitive and purest times."1

The evidence from the Early Liturgies, as to the time of the Fraction, is as follows :-In all, with the exception of the Abyssinian, the Fraction is made after the consecration of the elements. In some cases, the Lord's Prayer, etc., intervenes between the Fraction and the Communion, and is said in connexion with the reception : in other cases the Fraction follows the Lord's Prayer, and takes place immediately before Communion.

A. Fraction at our Lord's words [" He brake it"] only: Abyssinian. ("The Prayer of the Fraction" comes later.) $)^{2}$

B. Fraction at our Lord's words [" $\mathrm{He}$ brake it"] and again just before the Lord's Prayer: Coptic. ${ }^{3}$

c. Fraction just before the Lord's Prayer: St. James (Syriac), Coptic (see above), Nestorian, Egyptian.4 
D. Fraction after the Lord's Prayer, just before Communion: St. James (Greek), St. Mark (Greek), St. Chrysostom, Armenian. ${ }^{1}$

In all these cases the Lord's Prayer follows the consecration of the elements.

In St. John Damascene, the Fraction follows the elevation $^{2}$ : in James of Edessa (Letter to Thomas the Presbyter), it is before the Lord's Prayer, but after the consecration and intercession. ${ }^{3}$

Duchesne, in describing the Eucharist in the East, says that, after the consecration and certain prayers ended, "It was doubtless at this point that the Fraction of the bread took place, a ceremony which the documents of the fourth century do not mention in express terms : the Communion then took place." 4

It is therefore reasonable to enter a protest against the direction to break the bread at the moment indicated in the present rubric, before the consecration has been effected, as an unwarrantable interference with the order of proceeding adopted and inaugurated by our Lord at His institution of the Eucharist, and as contrary to practically universal liturgical precedent. In imitation of our Lord, to break the bread at the Communion of the celebrant and in the act of communicating the faithful, reverently and sufficiently fulfils all that is required. The adoption of this plan would effectively put an end to the undesirable practice of consecrating separate squares of bread or separate wafers, previously divided at the preparation of the element before service. By this method of severance, St. Paul's emphasis on the symbolism of the breaking of the one loaf ${ }^{5}$ is completely destroyed. We cannot be too jealous of any interference with the Divine order of proceeding as recorded in the New Testament. The symbolical Fraction of the mediaeval Church need not detain us here: we are concerned with New Testament records, and the light shed thereon by the Early Liturgies.

'Ibid., 62, 138, 393, 449. $\quad{ }^{4}$ Christian Worship, S.P.C.K., ii. \$2. 63.

2 Ibid., 486 , note 26 .

s Cor. x. 16, 17.

s Ibid., 492 . 
III. The directions for the celebrant to lay his hand upon the bread and the cup at the words, "This is my body ": "This is my blood," which in part only date from 1637 , and in whole from 1662 , are absolutely novel, finding no early or later precedent whatever. As far as ascertained at present, no trace of such a gesture at these words exists in any Catholic Liturgy known to scholars. The action is not even Roman. Here again the revisers of 1662 conspicuously disregarded the terms of the King's Commission at the Savoy Conference, referred to above. It is to be feared that the introduction of this novel gesture must be attributed to Cosin and the practice of the Caroline divines. In Cosin's Regni Angliae Religio Catholica, A.D. 1662, are the words :

Deinde, sese erigens, per preces solennes institutionem Sacramenti et ipsa Christi instituentis verba continentes, panem in manus acceptum frangens, vinumque in calicem effundens, utrumque symbolum benedicit, atque in Sacramentum Corporis et Sanguinis Christi consecrat. $^{1}$

In this passage " benedicit" is evidently the equivalent of the rubrics written in the margin of Cosin's Corrected Copy of the Prayer Book,A.D. I640-6I (see the table above), which direct the priest, at "This is my body," to hold his hands over the bread; and, at " This is my blood," to lay his hand upon the chalice, as directed in the Scottish Book of 1637. But it is to be noted that the Caroline divines had not shaken themselves free from the mediaeval and scholastic ideas which had become attached to the so-called " words of institution." As an example to illustrate what is meant, Bruno of Segni (A.D. I I23) may be quoted:

" When Christ said, 'This is my body,' and 'This is my blood," so great was the potency of His word, that instantly both the bread was changed into His Flesh, and the wine into His Blood. ... He spoke then for Himself : He speaks now through His ministers.",2

'Cosin's Works, Lib. A-C. Theol., iv. 359.

Bruno of Segni, Sententiarum, lib. iv. cap 9; Commentaria in Matth., P. iv., cap. 26, \$ 104. Patrologia Lat., clxv. 1005; 291. 
Similarly, Peter Lombard (A.D. I 164) goes so far as to assert that the consecration of the elements is effected by the mere recitation of the words, Hoc est corpus meum: Hic est sanguis mea-and that the rest of the Canon is said for the praise of God (reliqua ad laudem Dei dicuntur). ${ }^{1}$

It cannot be said too emphatically, that the words, " This is my body :" "This is my blood," were not our Lord's words of consecration, but His words of administration. We are told that He first " blessed and gave thanks," and thus consecrated the elements ; but we are not told the words which He used in so doing-no record survives. Then, after having so consecrated the elements, He proceeded to distribute them to His disciples, saying, as $\mathrm{He}$ did so, "Take, eat, this is my body," and similarly with the cup. There is absolutely no ground whatever for assuming, as the present rubrics at least suggest, that our Lord used the action of laying His hands upon the elements as He said, "This is my body ": "This is my blood." On the contrary, as He said these words whilst engaged in the act of breaking the bread and administering the bread and the cup, it is inconceivable that at the moment $\mathrm{He}$ used His sacred hands as is so unfortunately suggested by the rubrics. To assume that $\mathrm{He}$ did so, implies that $\mathrm{He}$ did not consecrate the elements until engaged in the very act of distributing them individually-in fact, that $\mathrm{He}$ did not consecrate by blessing and giving thanks previous to administration, as is stated in the New Testament.

And lastly, whilst many of the ancient Liturgies, from the Apostolic Constitutions onwards, assume that our Lord raised $\mathrm{His}$ eyes to heaven as $\mathrm{He}$ took the elements, ${ }^{2}$ they significantly omit any allusion to laying His hands upon them at the words, "This is my body": "This is my blood." The writer therefore ventures to urge that the two rubrics relating to imposition of hands

${ }^{1}$ Peter Lombard, Sententiarum, lib. iv., dist., viii. 3. De forma.

${ }^{2}$ e.g. Liturgy of St. James (Greek); Liturgy of St. Mark (Greek); Liturgy of Coptic Jacobites; Brightman, L. E. \& W., pp. 5r f., $132 \mathrm{f.}, 176$. Probably this gesture is assumed from St. Mark vi. $4 \mathrm{I}$. 
should be removed from their present position, as (I) suggesting a historical inaccuracy as to fact; as (2) giving to the words which they accompany and illustrate, a purpose and intention different from that with which our Lord spoke them; as (3) possessing, so placed, no liturgical precedent whatever.

If the gesture of laying on of hands upon the elements is to be retained-and it is fitting that it should be retained-the appropriate liturgical moment is at the saying of the oblique Invocation, which, in the Irish and English Prayer Books, abnormally ${ }^{1}$ precedes the recitation of the narrative of the Institution-namely, at the words :

Hear us, O merciful Father, we most humbly beseech Thee ; and grant that we receiving these Thy creatures of bread and wine, according to Thy Son our Saviour Jesus Christ's holy institution, in remembrance of His death and passion, may be partakers of His most blessed Body and Blood.

Sufficient has, I think, been said above to make it clear that the rubrics governing the Manual Acts arewith the exception of the direction to take the bread and the cup into the hands-most unsatisfactory; and that, out of reverence to our Lord's institution and with regard to true and sound liturgical precedent, they call for drastic revision when opportunity occurs.

\section{Vernon Staley.}

\footnotetext{
1 The ancient liturgical order is (1) The Narrative of Institution; (2) The Obation of the elements; (3) The Invocation or Prayer of Consecration. This order is preserved in the Liturgy of the American Church and in that of the Scottish Church.
} 